\title{
Seawater microorganisms have a high affinity glycine betaine uptake system which also recognizes dimethylsulfoniopropionate
}

\author{
Ronald P. Kiene ${ }^{1,2, *}$, Lynn P. Hofimann Williams ${ }^{1,2}$, Joel E. Walker ${ }^{1,2}$ \\ ${ }^{1}$ Department of Marine Sciences, University of South Alabama, Mobile, Alabama 36688, USA \\ ${ }^{2}$ Dauphin Island Sea Lab, Dauphin Island, Alabama 36528, USA
}

\begin{abstract}
In $24 \mathrm{~h}$ old seawater filtrate cultures, comprised mostly of free-living bacteria, the uptake of methyl- ${ }^{14} \mathrm{C}$-glycine betaine (GBT) displayed Michaelis-Menten-type saturation kinetics with halfsaturation constants $\left(\mathrm{K}_{1}\right)$ of $<5 \mathrm{nM}$. The uptake of $5 \mathrm{nM}{ }^{14} \mathrm{C}-\mathrm{GBT}$ was strongly inhibited by additions of 1 to $30 \mathrm{nM}$ unlabeled $\beta$-dimethylsulfoniopropionate (DMSP), a naturally occurring analog of GBT The dose response to DMSP was consistent with simple dilution of labeled GBT Conversely, the uptake of ${ }^{35} \mathrm{~S}-\mathrm{DMSP}$ was inhibited by the presence of GBT over a similar concentration range. Comparison of ${ }^{14} \mathrm{C}$-GBT and ${ }^{35}$ S-DMSP uptake kinetics in the presence and absence of unlabeled analogs suggested that GBT and DMSP act as competitive inhibitors of their respective uptake by seawater microbes. Direct comparisons of ${ }^{14} \mathrm{C}$-GBT and ${ }^{35} \mathrm{~S}$-DMSP uptake in filtrate cultures yielded nearly identical kinetic patterns. It was also found that a portion of the ${ }^{14} \mathrm{C}$-GBT taken up into particulate material could be chased from the particles by a 200-fold excess of unlabeled GBT or DMSP, whereas it was retained as untransformed ${ }^{14} \mathrm{C}$-GBT in the particles for several hours in unchased samples. A screening of organic compounds revealed that compounds with close structural similarity to GBT (DMSP, dimethylsulfonioacetate, proline betaine and dimethylglycine) strongly inhibited ( $<36 \%$ of controls) ${ }^{14} \mathrm{C}-\mathrm{GBT}$ uptake. Compounds showing moderate inhibition ( 48 to $89 \%$ of controls) included trigonelline, proline, glutamic acid, carnitine and choline, while compounds bearing no structural or chemical similarity to GBT (glycine, glucose, acrylic acid, and 3-methiolpropionate) had no effects on ${ }^{14} \mathrm{C}$-GBT uptake. Our results indicate that the GBT uptake system expressed by natural populations of microorganisms is multifunctional, displaying high affinity for both GBT and DMSP and possibly other naturally occurring betaine-like compounds. This microbial uptake system is likely to play an important role in the biogeochemical dynamics of GBT and DMSP.
\end{abstract}

KEY WORDS: Osmolytes - Transport $\cdot$ Bacteria $\cdot$ Dimethylsulfoniopropionate $\cdot$ Inhibitors

\section{INTRODUCTION}

Glycine betaine $\left[\left(\mathrm{CH}_{3}\right]_{3} \mathrm{~N}^{+} \mathrm{CH}_{2} \mathrm{COO}^{-}\right.$; trimethylglycine; $\mathrm{GBT}$ ] is a quaternary ammonium compound which is produced by a wide variety of marine organisms, including cyanobacteria, phytoplankton, macroalgae, halophytes and invertebrates (Cavalieri \& Huang 1981, King 1988, Anthoni et al. 1991). GBT appears to serve osmotic- and compatible-solute functions and it can occur at very high intracellular concentrations

•E-mail: rkiene@jaguar1.usouthal.edu (100s $\mathrm{mM}$ ) in the organisms which produce or accumulate it (Rhodes \& Hanson 1993). In fact, GBT is considered to be among the most effective and widely used compatible solutes found in nature (Yancey et al. 1982). GBT is particularly effective at minimizing the detrimental effects of low water activity on protein and membrane functions; a problem faced by all microorganisms living in saline habitats (Galinski 1995). Despite the widespread distribution of GBT, the fate of this organic nitrogen compound and its function in natural microbial communities remain poorly understood.

GBT is structurally, and perhaps functionally, similar to the tertiary sulfonium compound dimethylsulfonio- 
propionate [( $\left(\mathrm{CH}_{3}\right)_{2} \mathrm{~S}^{+} \mathrm{CH}_{2} \mathrm{CH}_{2} \mathrm{COO}^{-}$; DMSP], which occurs in many marine algae and is ubiquitous in the euphotic zone of coastal and oceanic waters (Turner et al. 1988, Iverson et al. 1989, Burgermeister et al. 1990). DMSP is the major precursor of volatile sulfur species such as dimethylsulfide (DMS) and methanethiol in aerobic marine waters (Andreae 1990, Kiene 1996a). These sulfur gases, especially DMS, can influence climate processes through their conversion to aerosols in the atmosphere (Charlson et al. 1987). The ability of marine bacteria to take up and degrade dissolved DMSP (DMSPd) is well established (Kiene \& Service 1991, Diaz et al. 1992, Ledyard \& Dacey 1994, Wolfe 1996, Yoch et al. 1997), but our understanding of DMSPd dynamics and its function in microbial communities is still rudimentary.

A wide variety of bacteria in culture, including Eschericia coli, Klebsiella sp. and Rhodobacter spheroides, take up GBI and related compounds for osmotic purposes (Le Rudulier \& Bouillard 1983, Perroud \& LeRudulier 1985, Abee et al. 1990). Some members of the Archaea also take up exogenous GBT (Proctor et al. 1997). Competitive inhibitor experiments suggest that the GBT transport system in Bacteria is multifunctional, being capable of transporting a number of structurally related osmoprotectants, including proline (Perroud \& LeRudulier 1985) and DMSP (Gouesbet et al. 1994). In most of the organisms studied to date, the high affinity GBT transport system (Pro U) displays apparent $K_{\mathrm{m}}$ values for GBT of 1 to $35 \mu \mathrm{M}$, values which are well above the typical $\mathrm{nM}$ concentrations of labile compounds found in seawater.

The uptake of low molecular weight solutes by seawater microorganisms has been studied in great detail (Wright \& Hobbie 1966, Ferguson \& Sunda 1984. Fuhrman 1987, Coffin 1989, Rich et al. 1996). Most of these studies have focused on amino acids and sugars, which are thought to be the main energy substrates of natural bacterioplankton. Osmotic solutes of marine plants, such as GBT and DMSP, have received much less attention. Because of their rapid utilization, monomeric, labile organic substrates are nearly always present at concentrations less than $1 \mu \mathrm{M}$ and are often in the low nanomolar range (Fuhrman \& Ferguson 1986, Mopper \& Kieber 1991). Uptake of substrates at these low concentrations requires high affinity transport systems to make efficient acquisition of the substrates possible (Button 1991).

We recently studied the uptake, retention and degradation of nanomolar levels of GBT in seawater (Kiene \& Hoffmann Williams unpubl.). We found that GBT was rapidly taken up by seawater microbes for use as a carbon/energy source and also possibly as an osmolyte. Here we present evidence which suggests that the uptake system responsible for transporting
GBT also recognizes DMSP and possibly other structurally related compounds. The presence of this high affinity uptake system in marine microorganisms is probably responsible for maintaining low dissolved concentrations of GBT and DMSP in seawater as well as a rapid and efficient turnover of these 2 biogeochemically important compounds.

\section{MATERIALS AND METHODS}

Sample collection and incubation. Estuarine and coastal water samples were collected from Mobile Bay, its plume and adjacent areas in the Northern Gulf of Mexico, near Dauphin Island, Alabama, USA. Mobile Bay samples were collected from either the east end pier $\left(30^{\circ} 15^{\prime} \mathrm{N}, 88^{\circ} 05^{\prime} \mathrm{W}\right)$ or the west end beach $\left(30^{\circ} 15^{\prime} \mathrm{N}, 88^{\circ} 11^{\prime} \mathrm{W}\right)$ on Dauphin Island using an acid rinsed bucket. The offshore samples were collected from small boats at sites located approximately 6 to $10 \mathrm{~km}$ south of Dauphin Island. In these cases surface water was collected directly into acid rinsed polycarbonate carboys. Water samples were held in the dark during transit back to the laboratory $(<1 \mathrm{~h})$. Salinities of the Mobile Bay and Gulf of Mexico samples ranged from 17 to 36 , and temperatures from 18 to $30^{\circ} \mathrm{C}$. Additional samples were collected from temperate waters in the Gulf of Maine, USA, during a research cruise aboard the RV 'Cape Hatteras' (cruise 0795, 16 to 25 June 1995). Water was collected from $5 \mathrm{~m}$ depth using 5 I Niskin bottles deployed on a rosette with a Seabird conductivity, temperature, and depth (CTD) analyzer. Temperature for the Gulf of Maine samples was $15^{\circ} \mathrm{C}$, and the salinity was 32 .

Our recent investigations revealed that it is predominantly the $<1 \mu \mathrm{m}$ sized organisms which are responsible for taking up GBT in seawater (Kiene \& Hoffmann Williams unpubl.). Therefore, in addition to using whole, unfiltered seawater, we used filtrate cultures containing primarily free-living bacteria in some experiments. Filtrate cultures were prepared by gravity filtering water through Whatman GF/F filters. Greater than $80 \%$ of the total bacterial population can pass through GF/F filters (Lee et al. 1995), and this was confirmed during our studies. Furthermore, our observations of the filtrates by epifluorecence microscopy showed that photoautotrophs and microzooplankton were largely excluded by the GF/F filters. Filtrates were incubated in the dark in 1.1 Teflon bottles $(\mathrm{HCl}$ rinsed) at room temperature $\left(23\right.$ to $25^{\circ} \mathrm{C}$ ) for 20 to $24 \mathrm{~h}$ prior to initiation of uptake experiments. The filtrate cultures offered some advantages over whole water for the study of the GBT uptake system. Whole water contains a significant ( 1 to $10 \mathrm{nM}$ ) pool of dissolved DMSP (and possibly GBT) which is variable over time 
due to release from DMSP-containing phytoplankton and other organisms. The presence of these substrate pools could have confounded the uptake experiments designed to look for competitive inhibition between GBT and DMSP. The gentle removal of phytoplankton and other DMSP-containing particles by gravity filtration minimized the release of dissolved organic compounds from phytoplankton, and preincubation of the filtrate cultures for $24 \mathrm{~h}$ allowed the bacteria-sized organisms to deplete endogenous dissolved DMSP (and by analogy GBT) to $<0.5 \mathrm{nM}$ prior to uptake measurements.

Uptake of ${ }^{14} \mathrm{C}$-GBT. Most of the experimental data presented in this report are for short-term ( $<10 \mathrm{~min}$ ) uptake rates of methyl- ${ }^{14} \mathrm{C}$-GBT into particles $>0.2 \mu \mathrm{m}$. Short incubations were chosen to minimize the fraction of added label taken up and the amount converted to degradation products. Previous results have shown that degradation of ${ }^{14} \mathrm{C}-\mathrm{GBT}$ to ${ }^{14} \mathrm{CO}_{2}$ is $<5 \%$ of total uptake in incubations of $10 \mathrm{~min}$ or less (Kiene \& Hoffmann Williams unpubl.). Short incubations also minimized the possibility of enzyme system induction in response to the added substrate. Further information on the uptake, retention and degradation of GBT during short and longer-term incubations in seawater will be presented elsewhere (Kiene \& Hoffmann Williams unpubl.). ${ }^{14} \mathrm{C}$-GBT uptake was measured by filtering 10 to $20 \mathrm{ml}$ water samples (usually in duplicate) onto $0.2 \mu \mathrm{m}$ Supor filters (Gelman) with a vacuum of $<10 \mathrm{~cm}$ $\mathrm{Hg}$. The filters were rinsed 3 times with $0.2 \mu \mathrm{m}$ filtered seawater of the same salinity, and placed into a $20 \mathrm{ml}$ scintillation vial with $5 \mathrm{ml}$ of Ecolume (ICN Biomedicals). Radioactivity on the filters was then determined using a Packard liquid scintillation counter using the external standard method. Sample blanks were negligible $(<20 \mathrm{dpm}$ per filter) for the amounts of isotope $\left(<5000 \mathrm{dpm} \mathrm{ml}^{-1}\right)$ used during these experiments. Concentrations of added ${ }^{14} \mathrm{C}$-GBT in each incubation bottle were determined directly by measuring the amount of radioactivity in sub-samples $(0.5$ or $1.0 \mathrm{ml})$ and applying the specific activity of the ${ }^{14} \mathrm{C}$ - $\mathrm{GBT}(57 \mathrm{mCi}$ $\mathrm{mmol}^{-1}$ )

Kinetic determinations. ${ }^{14} \mathrm{C}$-GBT uptake kinetics in filtrate cultures from Gulf of Mexico waters were determined by the Wright-Hobbie method (Wright \& Hobbie 1966). Briefly, several concentrations of ${ }^{14} \mathrm{C}$ GBT in the low nanomolar range $(0.5$ to $40 \mathrm{nM})$ were added to different water samples $(10$ or $20 \mathrm{ml}$ ) and incubated for short periods ( 5 or $10 \mathrm{~min}$ ). Uptake into filterable material (0.2 $\mu \mathrm{m}$ Supor) was measured and used to calculate uptake rates. Kinetic data were linearized by the Wright-Hobbie transformation in which the time of incubation divided by the fraction of added label taken up ( $t / f$ in hours) is plotted against the concentration of added label (nM) (Wright \& Hobbie
1966). In Wright-Hobbie plots, the slope of the line represents the inverse of the maximum uptake velocity (i.e. $1 / V_{\max }$ ), while the $y$-intercept represents the turnover time of the endogenous substrate pool $\left(S_{n}\right)$. The $x$-intercept represents $K_{\mathrm{t}}+S_{\mathrm{n}}$, which is the sum of the half saturation constant for transport by whole cells and the unknown endogenous substrate concentration. Use of non-linear regression to fit uptake data, as recommended by $\mathrm{Li}$ (1983), in most cases yielded kinetic parameters which did not differ by more than $10 \%$ from the Wright-Hobbie-predicted values. In some cases, however, the non-linear transformation yielded clearly spurious values of $V_{\max }$. We therefore chose to report only the Wright-Hobbie values. Double reciprocal plots using the Lineweaver-Burke transformation were also used when tests of competitive inhibition were made. ${ }^{35} \mathrm{~S}$-DMSP uptake kinetics in Gulf of Mexico filtrates were determined as for ${ }^{14} \mathrm{C}$-GBT.

Isotope dilution and competitive inhibitor experiments. The effects of unlabeled DMSP or GBT on uptake of ${ }^{14} \mathrm{C}$-GBT was tested. For this experiment seawater with a salinity of 30 was collected from $6 \mathrm{~km}$ offshore of Dauphin Island in the Gulf of Mexico. Upon return to the laboratory, a filtrate culture was generated by gravity filtering the water through a $142 \mathrm{~mm}$ Whatman GF/F filter into a carboy. The carboy of filtrate was incubated in the dark at $25^{\circ} \mathrm{C}$ for $24 \mathrm{~h}$ prior to initiation of the experiments. Individual bottles were filled with $20 \mathrm{ml}$ of the filtrate culture and treated with different amounts of unlabeled DMSP or GBT over the range of 1 to $30 \mathrm{nM}$. Immediately after addition of the unlabeled compounds, each sample received $5 \mathrm{nM}$ ${ }^{14} \mathrm{C}$-GBT and the incubation was allowed to proceed at $25^{\circ} \mathrm{C}$ for 6.5 or $8 \mathrm{~min}$ depending on the treatment. Total uptake of label into particulates was measured by filtering the samples onto Supor filters and then counting the filters in Ecolume. From the same filtrate culture, a kinetic series was carried out using different addition levels of ${ }^{14} \mathrm{C}$-GBT. In parallel with this, a ${ }^{14} \mathrm{C}$-GBT kinetic series which included a $5 \mathrm{nM}$ addition of unlabeled DMSP was also run

Dilution and kinetic experiments similar to those described above were carried out using ${ }^{35} \mathrm{~S}$-DMSP. These experiments, however, used a filtrate culture different than the one used for the ${ }^{14} \mathrm{C}$-GBT experiments. This filtrate culture was generated from Mobile Bay water with a salinity of 11 . Other differences in the protocol included the use of $10 \mathrm{nM}{ }^{35} \mathrm{~S}-\mathrm{DMSP}$ in the dilution experiment and $10 \mathrm{nM}$ unlabeled GBT in the kinetics experiment.

Cold chase experiment. An experiment was carried out to test whether ${ }^{14} \mathrm{C}$-GBT already taken up into particulates (cells) could be chased out of particulates by addition of unlabeled GBT or DMSP. A series of replicate, unfiltered water samples $(100 \mathrm{ml})$ from the 
Gulf of Maine were each treated with $5.5 \mathrm{nM}$ added ${ }^{14} \mathrm{C}-\mathrm{GBT}$ (69 $800 \mathrm{dpm} \cdot 100 \mathrm{ml}^{-1}$ ) and allowed to take up the label for $2 \mathrm{~h}$ at the in situ temperature $\left(15^{\circ} \mathrm{C}\right)$. At approximately $2 \mathrm{~h}, 1$ set of samples received a chase of unlabeled GBT and a second set received a chase of unlabeled DMSP (1000 nM final concentration each, respectively). A third set remained untreated as a control. Sample bottles were sacrificed over time and the amount of filterable $(0.2 \mu \mathrm{m}$ Supor) radioactivity in $50 \mathrm{ml}$ sub-samples was monitored before and after the addition of unlabeled compounds. For the non-chased samples, parallel $50 \mathrm{ml}$ sub-samples were filtered and analyzed for retention of ${ }^{14} \mathrm{C}-\mathrm{GBT}$ in the filterable material.

Retention of untransformed ${ }^{14} \mathrm{C}$-GBT in particulate material during the cold chase experiment was measured as previously described (Hoffmann 1996). Briefly, Supor filters, taken in parallel to those for total uptake (as above), were extracted in $5 \mathrm{ml}$ of methanol:chloroform:water (MCW 12:5:1) for $>24 \mathrm{~h}$. After removing and rinsing the filter, the $\mathrm{MCW}$ was evaporated to dryness under a stream of $\mathrm{N}_{2}$ at $45^{\circ} \mathrm{C}$, then reconstituted in $0.25 \mathrm{ml}$ water. The reconstituted extract was filtered, and injected into an HPLC with a cation exchange column for separation of GBT and collection of the peak fraction. Fractions corresponding to GBT peaks were collected with a Gilson Fraction collector, combined with $5 \mathrm{ml}$ Ecolume and counted by liquid scintillation methods.

Tests of other potential competitive inhibitors. A series of organic compounds were tested for their effects on the short-term uptake of ${ }^{14} \mathrm{C}$-GBT. Compounds were chosen based on their structural similarity to GBT (i.e. DMSP, dimethylsulfonioacetate, choline, proline, proline betaine, trigonelline, dimethylglycine, carnitine), their involvement in DMSP degradation pathways (i.e. acrylic acid, 3-methiolpropionate), or as representative biogeochemically important sugars (glucose) or amino acids (glycine, glutamic acid). Water from Mobile Bay (salinity $=11$, in situ temperature of $18^{\circ} \mathrm{C}$ ) was collected and held in a $10 \mathrm{l}$ carboy under normal room lighting. The water in the carboy was continually mixed with a stir bar at low speed. Just before an inhibitor test, $15 \mathrm{ml}$ aliquots from the carboy were dispensed into a series of $125 \mathrm{ml}$ serum bottles. Organic compounds to be tested were then added to a final concentration of $200 \mathrm{nM}$ (duplicate bottles for each compound). After thorough mixing, each sample received ${ }^{14} \mathrm{C}$-GBT to give a final concentration of $11 \mathrm{nM}$. Incubation proceeded for $10 \mathrm{~min}$ and was terminated by filtration onto $0.2 \mu \mathrm{m}$ Supor filters. The total uptake of ${ }^{14} \mathrm{C}$ onto the filters was determined by radioassay. Uptake in the experimental (inhibitor) samples was compared with controls receiving only ${ }^{14} \mathrm{C}$-GBT and a volume of water equivalent to the in- hibitor additions. Time constraints prevented more than 4 compounds from being tested in a single incubation. run. Therefore several runs were carried out over a $36 \mathrm{~h}$ period, all using water from the same carboy. Experimental treatments within each run were compared to controls ( ${ }^{14} \mathrm{C}-\mathrm{GBT}$ only) from the same run, which accounted for changes in gross uptake rates in the parent water sample. Tests of some of inhibitors, repeated $24 \mathrm{~h}$ apart, yielded similar results, indicating that changes in the microbial community in the parent water did not affect the comparisons. The endogenous dissolved GBT and DMSP concentrations in the water were not known, so the effective final concentration of the substrate for the uptake system was not known. Therefore, unlabeled GBT (200 nM) was added as a positive control inhibitor with which the other inhibitors could be compared.

Isotopes and other chemicals. Methyl- $\left[{ }^{14} \mathrm{C}\right]$ glycine betaine was synthesized from ${ }^{14} \mathrm{C}$-choline (ICN Biomedicals), following the procedures outlined by King (King 1987). The methyl-[14 C]GBT synthesized had a specific activity of $57 \mathrm{mCi} \mathrm{mmol}^{-1}$. Radiochemical purity was $>99 \%$ based on HPLC and thin layer chromatography. The primary stock was stored in ethanol at $4^{\circ} \mathrm{C}$. Working stocks for addition to samples were prepared by evaporating the ethanolic stock on the day of use and reconstituting it in $18 \mathrm{M} \Omega$ water. Addition volumes of the isotope stock to seawater were always $<1 \%$ of the sample volume.

${ }^{35} \mathrm{~S}$-DMSP was synthesized by feeding a growing, axenic culture of the phytoplankter Platymonas (= Tetraselmis) subcordiformis $100 \mu \mathrm{Ci}(2.3 \mathrm{nM})$ of ${ }^{35} \mathrm{~S}$ L-methionine $\left(1458 \mathrm{Ci} \mathrm{mmol}^{-1}\right.$; obtained from ICN Biomedicals). This species had previously been shown to take up exogenous methionine from the medium (Grone \& Kirst 1992). The culture was grown in $30 \mathrm{ml}$ $\mathrm{F} / 2$ medium under fluorescent lights (14 h light:10 h dark) in a fume hood. The phytoplankton cells were harvested after several days, when $70 \%$ of the added label had been taken up into the cells. Cells were gently filtered onto $0.45 \mu \mathrm{m}$ Supor filters $(5 \mathrm{ml}$ culture per filter) and the filters placed in $5 \mathrm{ml}$ of methanol:chloroform:water (MCW 12:5:1) to extract ${ }^{35}$ S-DMSP and other soluble components. After $>48$ h the extract was dried. under a stream of $\mathrm{N}_{2}\left(45^{\circ} \mathrm{C}\right)$ and reconstituted in water The reconstituted extract was then passed through a cation exchange column (Dowex-50; $\mathrm{H}^{+}$ form) which retained DMSP. After rinsing the column with pure water, the ${ }^{35} \mathrm{~S}$-DMSP was eluted with $6 \times$ $1 \mathrm{ml}$ rinses of $2 \mathrm{M} \mathrm{HCl}$. The $\mathrm{HCl}$ fraction was evaporated to dryness and reconstituted in water. The ${ }^{35} \mathrm{~S}$ DMSP was separated from GBT and other onium compounds (principally homarine) by injecting the extract (90 $\mu \mathrm{l}$ at a time) into an HPLC with a Partisil cation exchange column (4.5 mm i.d. $\times 250 \mathrm{~mm}$ length). The 
eluent was $50 \mathrm{mM} \mathrm{KH}_{2} \mathrm{PO}_{4}$ with $2.5 \%$ methanol. The peak fractions containing the ${ }^{35} \mathrm{~S}$-DMSP were collected, pooled and then passed through a Dowex 50 column which retained the DMSP but allowed $\mathrm{PO}_{4}^{3-}$ to be rinsed through. After thorough rinsing, the ${ }^{35} \mathrm{~S}$ DMSP was eluted from the column with $2 \mathrm{M} \mathrm{HCl}$, which was subsequently evaporated. The final extract was reconstituted in $1: 1$ ethanol: $\mathrm{H}_{2} \mathrm{O}$ and stored at $4^{\circ} \mathrm{C}$. The final yield was $8.8 \mu \mathrm{Ci}$, which represented about $9 \%$ of the added ${ }^{35} \mathrm{~S}$-methionine. The specific activity at the time of purification was determined to be $37 \mathrm{mCi}$ $\mathrm{mmol}^{-1}$ by combined gas chromatographic analysis of DMS generated from the DMSP (Kiene \& Service 1991) and liquid scintillation methods. This specific activity is far below that of the parent ${ }^{35} \mathrm{~S}$-methionine because of the substantial production of unlabeled DMSP by the culture. Radiochemical purity of the ${ }^{35}$ S-DMSP was determined to be $>98 \%$ based on HPLC analysis. On the day of use, an aliquot of the primary stock was evaporated to remove ethanol and reconstituted in $18 \mathrm{M} \Omega$ water.

Unlabeled GBT was obtained from Sigma as either the $\mathrm{HCl}$ salt or the anhydrous form. DMSP.HCl was obtained from Research Plus Inc. Dimethylsulfonioacetate was a gift from Mark deSouza. Proline betaine was a gift from David Rhodes. 3-methiolpropionate was synthesized from its methyl ester (Sigma) by alkaline hydrolysis. All other organic chemicals were $a b$ tained from either Sigma or Aldrich and were the highest purity available. Stocks were prepared fresh on the day of use.

\section{RESULTS}

\section{Kinetics of GBT uptake in filtrate cultures}

Uptake of ${ }^{14} \mathrm{C}$-GBT in filtrate cultures displayed Michaelis-Menten type saturation kinetics (Fig. 1A). Transformation of the uptake rate data using the Wright-Hobbie method yielded a good linear fit $\left(\mathrm{r}^{2}>0.98 ; \mathrm{n}=25\right)$ (Fig. 1B). Similar uptake kinetics were observed in 5 different filtrate cultures generated from seawater collected in the northern Gulf of Mexico near Dauphin Island. Linearization of these data sets yielded estimates of kinetic parameters for GBT uptake (Table 1). The $K_{\mathrm{t}}+S_{\mathrm{n}}$ values ranged from 0.86 to $4.5 \mathrm{nM}$ and were close to $4 \mathrm{nM}$ in 3 out of the 5 experiments. $V_{\max }$ values ranged from 2.4 to $27 \mathrm{nM} \mathrm{h}^{-1}$, and turnover times were very short $(0.15$ to $1.8 \mathrm{~h})$. Bacterial abundances were measured in several of the filtrate cultures and these ranged from 2.2 to $2.3 \times$ $10^{9}$ cells $1^{-1}$. Using these abundances, the cell specific $V_{\max }$ values for the 2 experiments were $3 . \dot{8}$ and $1.0 \times$ $10^{-18} \mathrm{~mol} \mathrm{cell}{ }^{-1} \mathrm{~h}^{-1}$ for 31 July and 5 August $1997 \mathrm{re}$ -
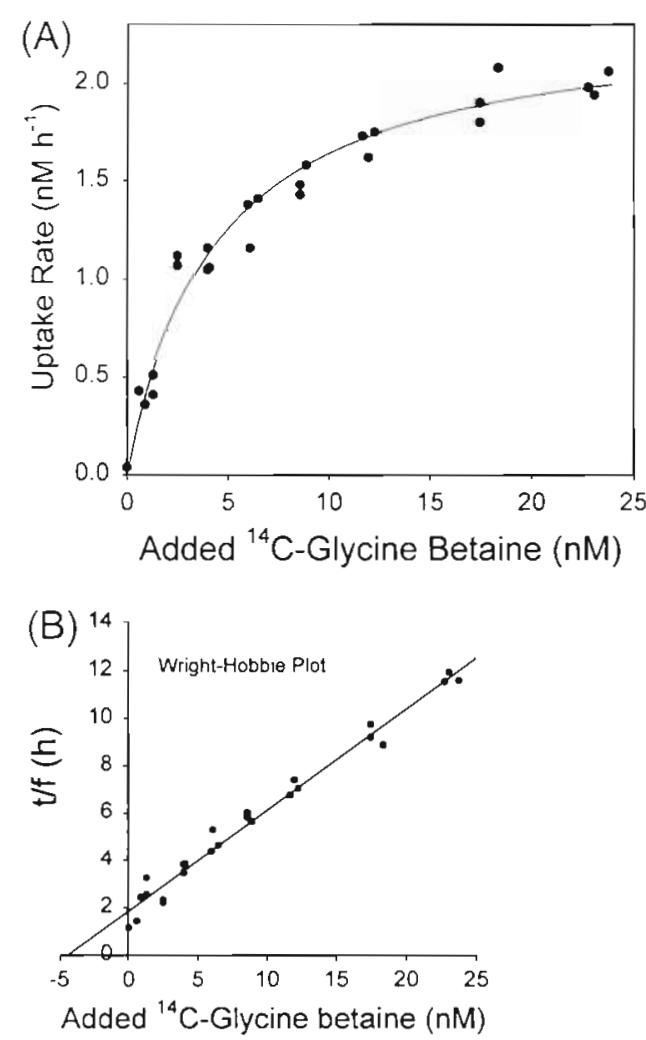

Fig. 1 (A) Uptake kinetics of methyl ${ }^{14} \mathrm{C}$-glycine betaine in a 24 h old seawater filtrate culture. Points represent measured incorporation of ${ }^{14} \mathrm{C}$-glycine betaine into particles $>0.2 \mu \mathrm{m}$ during a $10 \mathrm{~min}$ incubation. The curve represents the predicted rates based on Michaelis-Menten kinetics using a $V_{\max }$ of $2.36 \mathrm{nM} \mathrm{h}^{-1}$ and a half saturation constant $\left(K_{1}\right)$ of $4.39 \mathrm{nM}$. (B) Wright-Hobbie plot of uptake rate data, used to calculate kinetic parameters. Seawater for this experiment was collected from a beach on the west end of Dauphin Island, AL. USA and had a salinity of 28 . Incubation temperature was $25.5^{\circ} \mathrm{C}$

spectively. No evidence for multiphasic kinetics (Azam \& Hodson 1981) was observed with filtrate cultures, whereas this has been observed in whole water samples (Walker \& Kiene unpubl. data). GBT uptake was biological, as it was inhibited completely by autoclaving, treatment with formalin or removal of organisms by $0.2 \mu \mathrm{m}$ filtration (data not shown). In addition, GBT uptake displayed temperature optima in Mobile Bay waters (Kiene \& Hoffmann Williams unpubl.), a strong indication of biological activity.

\section{Dilution and competitive inhibitor experiments}

Preliminary experiments carried out with water samples from the Gulf of Maine in 1995 indicated that DMSP was a potent inhibitor of ${ }^{14} \mathrm{C}$-GBT uptake and that the dose response was consistent with simple dilu- 
Table 1. Kinetic parameters for methyl- ${ }^{14} \mathrm{C}$-glycine betaine uptake in filtrate cultures generated from Gulf of Mexico coastal waters Kinetic parameters were obtained from Wright-Hobbie linearizations of uptake rate data as a function of added ${ }^{14} \mathrm{C}$-GBT concentration. Incubations were for either 5 or $10 \mathrm{~min}$. Filtrate cultures were generated by dripping seawater through Whatman GF/F filter, then pre-incubating the culture for $\sim 24 \mathrm{~h}$ prior to the initiation of uptake measurements. $K_{\mathrm{l}}+S_{\mathrm{n}}$ : sum of half saturation constant and unknown endogenous substrate concentration; $V_{\max }$ : maximum uptake velocity

\begin{tabular}{|c|c|c|c|c|c|c|c|}
\hline Sample date & Location & Salinity & $\begin{array}{l}\text { Temperature } \\
\qquad\left({ }^{\circ} \mathrm{C}\right)\end{array}$ & $\begin{array}{l}\text { Bacterial abundance } \\
\left(\times 10^{9} \text { cells }^{-1}\right)\end{array}$ & $\begin{array}{l}K_{\mathrm{t}}+S_{\mathrm{n}} \\
(\mathrm{nM} \mathrm{M})\end{array}$ & $\frac{V_{\max }}{\left.\text { (nmol } \mathrm{I}^{-1} \mathrm{~h}^{-1}\right)}$ & $\begin{array}{l}\text { Turnover time } \\
\text { (h) }\end{array}$ \\
\hline 15 Aug 1996 & $\begin{array}{l}6 \mathrm{~km} \text { south of Dauphin Island } \\
30^{\circ} 11.4^{\prime} \mathrm{N}, 88^{\circ} 09.9^{\prime} \mathrm{W}\end{array}$ & 30 & 25 & No data & 0.86 & 3.1 & 0.28 \\
\hline 22 Nov 1996 & $\begin{array}{l}\text { Sea Buoy, } 10 \mathrm{~km} \text { south of } \\
\text { Dauphin Island } \\
30^{\circ} 07.6^{\prime} \mathrm{N}, 88^{\circ} 04.2^{\prime} \mathrm{W}\end{array}$ & 34 & 20 & No data & 4.0 & 27 & 0.15 \\
\hline 12 Jun 1997 & $\begin{array}{l}\text { Dauphin Island West End Beach } \\
30^{\circ} 14.7^{\prime} \mathrm{N}, 88^{\circ} 11.0^{\prime} \mathrm{W}\end{array}$ & 18 & 26 & No data & 4.5 & 7.7 & 0.58 \\
\hline 31 Jul 1997 & Dauphin Island West End Beach & 17 & 27 & 2.2 & 2.0 & 8.4 & 0.24 \\
\hline 5 Aug 1997 & Dauphin Island West End Beach & 29 & 27 & 2.3 & 4.4 & 2.4 & 1.8 \\
\hline
\end{tabular}

tion of the isotope by DMSP (data not shown). Similar experiments were then carried out with filtrate cultures generated from Gulf of Mexico shelf waters (Fig. 2). Addition of unlabeled DMSP or GBT inhibited ${ }^{14} \mathrm{C}$-GBT uptake in a manner consistent with isotope dilution. In light of our inability to measure endogenous GBT concentrations, inclusion of the positive control treatment (unlabeled GBT) served to confirm that the dilution of the radiolabeled substrate was as expected. Somewhat greater uptake than predicted at the higher added concentrations may have been due to

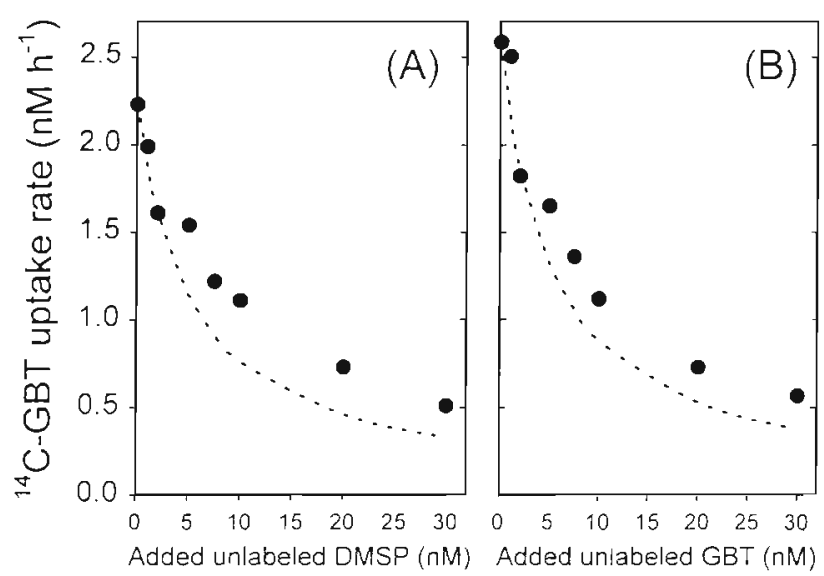

Fig. 2. Effects of adding different concentrations of (A) nonlabeled DMSP or (B) non-labeled glycine betaine (GBT) on the uptake rate of $5 \mathrm{nM}$ methyl- ${ }^{14} \mathrm{C}$-glycine betaine in $24 \mathrm{~h}$ old seawater filtrate cultures. Dotted lines represent the predicted rate based on simple isotope dilution by the amended compound. Incubation time was $6.5 \mathrm{~min}$ for the DMSP samples and 8 min for the GBT samples. Approximately $2 \mathrm{~h}$ separated the DMSP series from the GBT series, which may explain the slightly different rates in the 2 series. Seculater was collected on August 15, 1996, in the Gulf of Mexico, $6 \mathrm{~km}$ south of Dauphin Island, AL, USA $\left(30^{\circ} 11^{\prime} \mathrm{N}, 88^{\circ} 09^{\prime} \mathrm{W}\right)$. The water had a salinity of 30 and was incubated at $25^{\circ} \mathrm{C}$ the fact that the $5 \mathrm{nM}{ }^{14} \mathrm{C}$-GBT added was below the level needed to reach maximum uptake rates. When additional non-labeled substrate (DMSP or GBT) was added, the uptake rate probably increased slightly (see the concentration dependence of uptake for these same samples in Fig. 3). To test whether DMSP behaved as a competitive inhibitor, a kinetic series for GBT uptake was carried out with, and without, added DMSP using the same filtrate culture as used for the dilution experiment. The presence of $5 \mathrm{nM}$ DMSP slowed the rate of ${ }^{14} \mathrm{C}$-GBT uptake at any given concentration of GBT (Fig. 3A), and the Wright-Hobbie linearized plots yielded parallel lines with different $x$ and $y$-intercepts (Fig. 3B). Lineweaver-Burke double reciprocal plots of the same uptake data yielded lines with different slopes, but with identical $y$-intercepts (not shown). The results show a classic pattern of competitive inhibition of GBT uptake by DMSP.

A similar experiment in which radiolabeled DMSP uptake was measured (10 nM ${ }^{35} \mathrm{~S}$-DMSP added) showed that the uptake of this compound decreased as higher concentrations of unlabeled GBT or DMSP were added (Fig. 4). A kinetic series for ${ }^{35} \mathrm{~S}$-DMSP uptake with, and without, $10 \mathrm{nM} \mathrm{GBT}$ showed that uptake of DMSP was slower in the presence of GBT over a range of ${ }^{35}$ S-DMSP concentrations (Fig. 5A). Linear transformation of these uptake data by the Wright-Hobbie method yielded nearly parallel lines (Fig. 5B), while Lineweaver-Burke transformations yielded different slopes and nearly identical intercepts (not shown).

A direct comparison of ${ }^{14} \mathrm{C}-\mathrm{GBT}$ and ${ }^{35} \mathrm{~S}$-DMSP up take in the same filtrate culture revealed nearly identical kinetic patterns for the 2 compounds (Fig. 6). The $K_{\mathrm{t}}+S_{\mathrm{r}}$ values were 2.0 and $3.8 \mathrm{nM}$ for GBT and DMSP respectively. The $V_{\max }$ values were 8.4 and $8.9 \mathrm{nM} \mathrm{h}^{-1}$, and the turnover times were 0.24 and $0.43 \mathrm{~h}$ for GBT and DMSP respectively. 

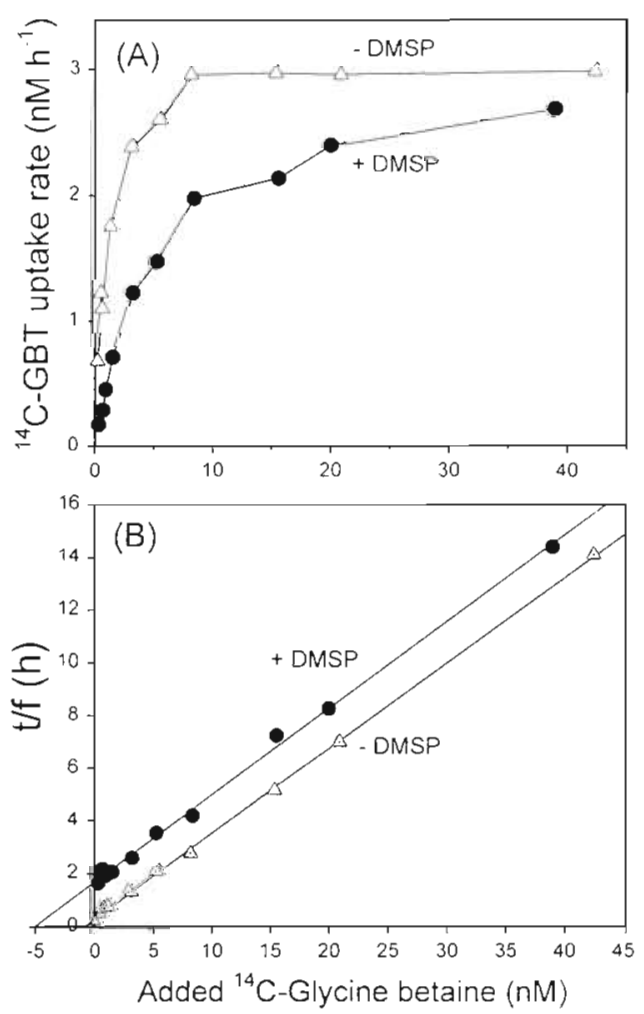

Fig. 3. Uptake kinetics of methyl- ${ }^{14} \mathrm{C}$-glycine betaine by a $24 \mathrm{~h}$ old seawater filtrate culture in the presence and absence of $5 \mathrm{nM}$ non-labeled DMSP. (A) Uptake rate as a function of added ${ }^{14} \mathrm{C}$-GBT. (B) Wright-Hobbie linearized uptake rate data. The line represents a linear least squares fit to the data. Seawater was collected on August 15, 1996, in the Gulf of Mexico, $6 \mathrm{~km}$ south of Dauphin Island, AL, USA $\left(30^{\circ} 11^{\prime} \mathrm{N}\right.$, $88^{\circ} 09^{\prime} \mathrm{W}$ ). The water had a salinity of 30 and was incubated at $25^{\circ} \mathrm{C}$

\section{Cold chase experiment}

In Gulf of Maine samples, $5 \mathrm{nM}{ }^{14} \mathrm{C}$-GBT was taken up rapidly into particles, and a significant fraction of the isotope captured on $0.2 \mu \mathrm{m}$ filters was retained as ${ }^{14} \mathrm{C}$-GBT over a $5 \mathrm{~h}$ incubation period (Fig. 7). After the isotope in the particulate fraction had reached near maximal levels (at $\sim 2 \mathrm{~h}$ ), the addition of $1000 \mathrm{nM}$ unlabeled GBT or DMSP (182-fold excess over label) caused a decline in the amount of isotope captured on filters (Fig. 7). The decline was slower than the initial uptake. The results suggest that a portion of the ${ }^{14} \mathrm{C}$ GBT taken up is exchangeable with the external pool, but apparently with slower kinetics than uptake.

\section{Tests of other potential competitive inhibitors}

Samples treated with compounds that have no close structural or chemical similarity to GBT, including glu-
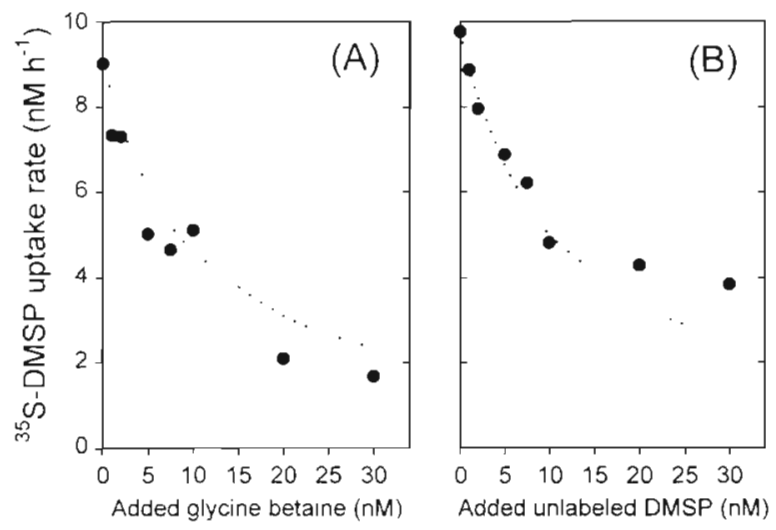

Fig. 4. Effects of adding different concentrations of (A) nonlabeled glycine betaine or (B) non-labeled DMSP on the uptake rate of $10 \mathrm{nM}{ }^{35} \mathrm{~S}-\mathrm{DMSP}$ in $24 \mathrm{~h}$ old filtrate cultures generated from Mobile Bay water (salinity $=11$ ). Dotted lines represent the predicted rate based on simple isotope dilution by the amended compound. Incubation time for each subsample was $5 \mathrm{~min}$. Approximately $2 \mathrm{~h}$ separated the GBT series from the DMSP series, which may explain the slightly different rates in the 2 series. Incubation was at $26^{\circ} \mathrm{C}$
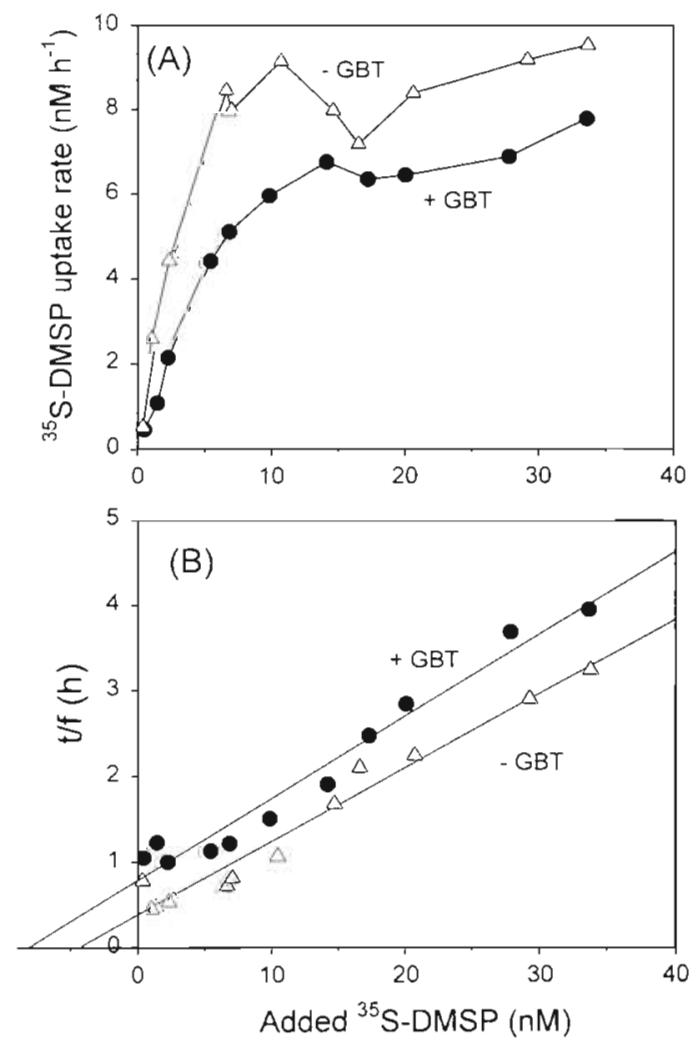

Fig. 5. Uptake kinetics of ${ }^{35} \mathrm{~S}-\mathrm{DMSP}$ by a $24 \mathrm{~h}$ old seawater filtrate culture in the presence and absence of $10 \mathrm{nM}$ added glycine betaine. (A) Uptake rate as a function of added ${ }^{35} \mathrm{~S}$ DMSP. (B) Wright-Hobbie linearized uptake rate data. Water used for this experiment had a salinity of 11 and was collected from the pier on Dauphin Island, AL, USA. Incubation was at $26^{\circ} \mathrm{C}$ 


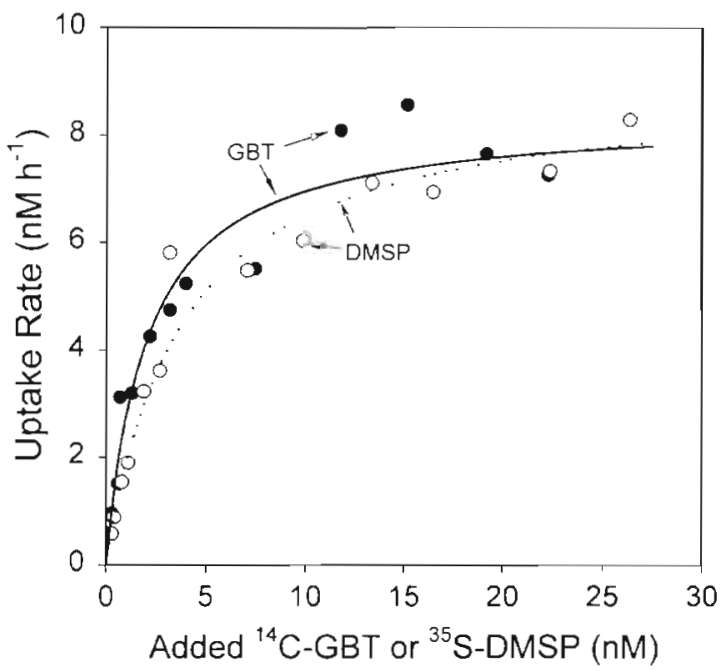

Fig. 6. Comparison of ${ }^{14} \mathrm{C}$-GBT (•) and ${ }^{35} \mathrm{~S}$-DMSP (0) uptake kinetics in sub-samples from a single filtrate culture. Individual points represent the uptake rates measured at different concentrations. Curves represent the predicted rates based on Michaelis-Menten kinetics using a $V_{\max }$ of $8.37 \mathrm{nM} \mathrm{h}^{-1}$ and a half saturation constant $\left(K_{1}\right)$ of $2.04 \mathrm{nM}$ for GBT and a $V_{\max }$ of $8.94 \mathrm{nM} \mathrm{h}^{-1}$ and a half saturation constant of $3.77 \mathrm{nM}$ for DMSP. Kinetic parameters were derived from the WrightHobbie linearization of the uptake rate data and by assuming that the endogenous substrate concentration $\left(S_{n}\right)$ was zero. Water was collected from the Dauphin Island Pier and had a salinity of 17 . Incubation was at $27^{\circ} \mathrm{C}$

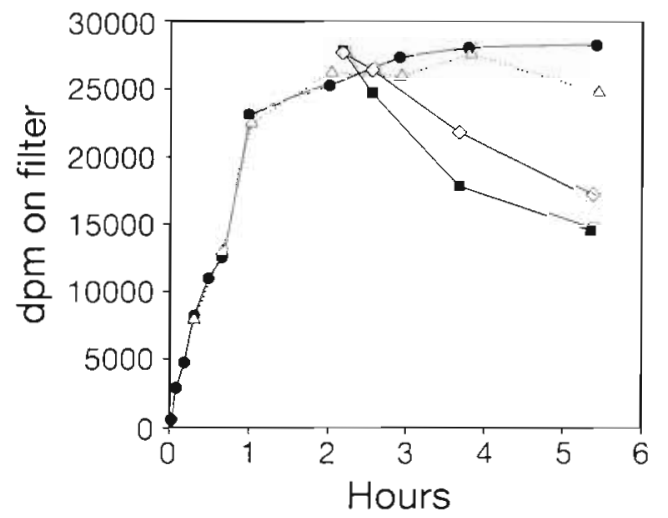

Fig. 7. The effects of adding a non-radioactive chase of either GBT or DMSP on retention of ${ }^{14} \mathrm{C}$ activity in seawater particulates after the uptake of ${ }^{14} \mathrm{C}$-GBT Whole seawater samples from the central Gulf of Maine were treated with $5.5 \mathrm{nM}^{14} \mathrm{C}$ GBT and uptake into particulates was monitored by filtration of samples onto $0.2 \mu \mathrm{m}$ Supor filters. At approximately $2 \mathrm{~h}$ into the incubation, parallel sets of samples were chased with $1000 \mathrm{nM}$ additions of non-labeled GBT ( $\mathbf{0})$ or DMSP $(0)$, while another set $(\bullet)$ was left untreated. The amount of ${ }^{14} \mathrm{C}$-GBT in the filterable material of unchased samples is also shown $(\Delta)$ and indicated that most of the radioactivity taken up remained as untransformed ${ }^{14} \mathrm{C}$-GBT Each $50 \mathrm{ml}$ sample (the volume filtered at each time point) received $34800 \mathrm{dpm}$ of ${ }^{14} \mathrm{C}-\mathrm{GBT}$ at time zero. The salinity of these samples was 32 and the incubation temperature was $15^{\circ} \mathrm{C}$
Table 2. Effects of various organic compounds on short-term (10 min) uptake of ${ }^{14} \mathrm{C}$-glycine betaine in estuarine water. All treatment compounds were added at a concentration of $200 \mathrm{nM}$ just prior to addition of $11 \mathrm{nM}{ }^{14} \mathrm{C}$-GBT The amount of ${ }^{14} \mathrm{C}$ uptake into particles $>0.2 \mu \mathrm{m}$ was measured after 10 min incubations, and the data are expressed as the percent of uptake measured in untreated controls $\left({ }^{34} \mathrm{C}-\mathrm{GBT}\right.$ only). Values represent the mean \pm the range of duplicate determinations. Salinity of the water was 11 and the incubation temperature was $23^{\circ} \mathrm{C}$

\begin{tabular}{|lc|}
\hline Treatment compound & Percent of uptake in control \\
\hline None (control) & $100 \pm 6.1$ \\
Glycine & $106 \pm 0.1$ \\
Acrylic acid & $97 \pm 3.7$ \\
Glucose & $96 \pm 0.4$ \\
3-methiolpropionate & $95 \pm 2.0$ \\
Choline & $89 \pm 0.9$ \\
Carnitine & $84 \pm 1.3$ \\
L-glutamic acid & $63 \pm 0.5$ \\
L-proline & $53 \pm 8.8$ \\
Trigonelline & $48 \pm 0.5$ \\
N,N-dimethylglycine & $36 \pm 5.7$ \\
Prolinebetaine & $31 \pm 1.0$ \\
Dimethylsulfonioacetate & $27 \pm 1.1$ \\
Dimethylsulfoniopropionate & $20 \pm 2.1$ \\
Glycinebetaine & $14 \pm 0.1$ \\
\hline
\end{tabular}

cose, acrylic acid, or 3-methiolpropionate, had rates of ${ }^{14} \mathrm{C}$-GBT uptake which were within $10 \%$ of the control rates, indicating no substantial inhibitory effects when these compounds were present at 20 -fold excess over ${ }^{14} \mathrm{C}$-GBT. On the other hand, addition of compounds which are more closely related to GBT produced greater inhibition. Of the compounds tested, the most potent inhibitor, other than unlabeled GBT itself, which gave $14 \%$ of the control, was DMSP $(20 \%$ of control) (Table 2). Dimethylsulfonioacetate, prolinebetaine and dimethylglycine produced moderately strong inhibition $(27,31$ and $36 \%$ of controls respectively), while choline, carnitine, glutamic acid, proline and trigonelline showed only modest inhibition ( 48 to $89 \%$ of controls).

\section{DISCUSSION}

The results presented here provide strong evidence that seawater microorganisms take up GBT and DMSP by a common, high affinity transport system. Our results show clearly that GBT uptake was inhibited by DMSP and that, conversely, DMSP uptake was inhibited by GBT (Figs. 2-5). Moreover, direct comparisons of the ${ }^{14} \mathrm{C}$-GBT and ${ }^{35} \mathrm{~S}$-DMSP uptake kinetics in filtrate cultures showed that, over the range of concentrations used ( 0.5 to $27 \mathrm{nM})$, both compounds were taken up at nearly the same rates and with the same 
concentration dependence (Fig. 6). The uptake system appears to be expressed constitutively in seawater from a variety of locations, including temperate waters (Kiene \& Hoffmann Williams unpubl.), and is able to rapidly scavenge DMSP and GBT at the low nanomolar concentrations expected for these compounds in seawater. The uptake of GBT and DMSP that we observed in $<0.8 \mu \mathrm{m}$ filtrate cultures can probably be attributed mainly to heterotrophic bacteria because microscopic examinations showed that eucaryotes and cyanobacteria were much less abundant than bacteria at the time experiments were carried out.

\section{Characteristics of the uptake system}

The GBT uptake system in natural populations of marine microorganisms displays characteristics which are similar in some respects to the well-studied GBT uptake system identified in the Enterobacteriacea and other bacteria (Cairney et al. 1985, Perroud \& LeRudulier 1985, Abee et al. 1990, Le Rudulier et al. 1996), particularly in regard to substrate specificity (Perroud \& LeRudulier 1985, Gouesbet et al. 1994). As in the studies with Escherichia coli, we found that close structural analogs, including DMSP, DMSA, and proline betaine are quite effective inhibitors of GBT uptake (Table 2). Other known osmoprotectant compounds with some structural similarity to GBT were inhibitory, but less so than the closer analogs. Proline for example, gave a $53 \%$ inhibition of GBT uptake in our assay (Table 2). Proline is known to be transported by the Pro $\mathrm{U}$ osmoporter in bacteria, but Pro $\mathrm{U}$ has a much lower affinity for proline as compared with GBT (Le Rudulier et al. 1996). This may explain why proline exhibited only moderate inhibitory effects on GBT transport (Table 2 ; see also (Perroud \& LeRudulier 1985). From the present study, and those mentioned above, it seems that an onium functionality, in close proximity to a carboxyl group, is critical for the recognition by this transport system. Worth mentioning in this regard is the possibility that other naturally occurring analogs of GBT, such as arsenobetaine and dimethylselenoniumpropionate (DMSeP) (the arsenic and selenium analogs of GBT and DMSP) (Cooke \& Bruland 1987, Hanaoka et al. 1987) might also be taken up by this system. Ansede \& Yoch (1997), for example, have recently reported that DMSeP was taken up and degraded by marine bacteria which utilized DMSP Compounds lacking both of the essential functional groups (e.g. glucose, acrylic acid, glycine) had no appreciable effects on GBT transport during our short assays, indicating they were not substrates for the uptake system. It should be noted, however, that enrichment of bacteria in filtrate cultures, with either
$100 \mu \mathrm{M}$ glucose or acrylic acid as substrates, enhanced cell-specific GBT uptake rates after $48 \mathrm{~h}$ (Kiene \& Hoffmann Williams unpubl.).

The inhibitor results discussed above are consistent with several recent studies which have found GBT to inhibit uptake of DMSP in bacterial isolates (Wolfe 1996, Yoch et al. 1997) or natural water samples (Kiene \& Gerard 1995). Kiene and Gerard tested a variety of betaine-like compounds for effects on DMSP loss and degradation in coastal seawater samples and found that at 1 to $50 \mu \mathrm{M}$ concentrations, GBT was a very effective inhibitor of DMSP degradation. In that study, $\beta$-alanine betaine was also found to be a potent inhibitor of DMSP degradation. Proline, dimethylglycine and carnitine showed intermediate effects on DMSP degradation, similar to their effects on GBT uptake in the present study (Table 2). Choline $\left[\left(\mathrm{CH}_{3}\right)_{3} \mathrm{~N}^{+} \mathrm{CH}_{2} \mathrm{COH}\right]$ on the other hand showed little effect on DMSP degradation (Kiene \& Gerard 1995) or on GBT uptake (Table 2), suggesting that the GBT/DMSP uptake system does not effectively recognize this compound. This was the same conclusion reached with regard to choline uptake by the Pro U system in Escherichia coli (Perroud \& LeRudulier 1985). Interestingly, choline is taken up from the medium and converted to GBT in a wide variety of bacterial cultures (Landfald \& Strom 1986, Choquet et al. 1991, Boch et al. 1994), and choline is present in seawater (Roulier et al. 1990). We have recently measured choline uptake in seawater and found that nanomolar levels are rapidly taken up by microorganisms. $K_{\mathrm{t}}+S_{\mathrm{n}}$ values for choline were similar to those of GBT and DMSP reported here (Kiene 1998). In addition, a substantial fraction of the choline taken up was converted to intracellular GBT, some of which was retained by the cells. Thus, choline, while not a substrate for the GBT transport system, could affect the dynamics of GBT and DMSP by being a source of GBT.

A notable exception to the similarity between the GBT uptake systems in bacterial cultures and in the natural populations is that the half saturation constants for GBT and DMSP uptake that we measured in the natural populations (apparent $K_{\mathrm{t}}<5 \mathrm{nM}$; Table 1) are at least 3 orders of magnitude lower than those measured for GBT in pure cultures (Cairney et al. 1985, Perroud \& LeRudulier 1985, Abee et al. 1990). The $K_{\mathrm{t}}+S_{\mathrm{n}}$ values for GBT measured in filtrate cultures ranged from 0.86 to $4.5 \mathrm{nM}$ (Table 1 ). It is probable that these values mostly reflect the half saturation constant $\left(K_{t}\right)$ because the endogenous substrate concentration was likely to be very low. Dissolved DMSP concentrations, for example, were typically below the detection limit of $0.5 \mathrm{nM}$ in $24 \mathrm{~h}$ old filtrate cultures (unpubl. obs.). The $K_{\mathrm{t}}+S_{\mathrm{n}}$ values for $\mathrm{GBT}$ observed in filtrate cultures were similar to, but generally lower than those 
measured in whole, unfiltered seawater from the same locations (range 1.2 to $49 \mathrm{nM}$ ) (Kiene \& Hoffmann Williams unpubl.). Whole seawater usually contained a higher DMSPd concentration than the filtrate cultures because of the release of DMSP from phytoplankton. In addition, some dissolved GBT may also have been present, contributing to the substrate pool for the GBT uptake system. A higher $S_{n}$ may partially explain the higher $K_{\mathrm{t}}+S_{n}$ values observed with whole water, but other factors, such as the role of attached bacteria, or possibly phytoplankton (Hoffmann 1996), with lower affinities for GBT could also contribute to this observation. The low $K_{\mathrm{t}}+S_{\mathrm{n}}$ values that we observed for GBT and DMSP uptake are in the same range as those measured for individual dissolved free amino acids in seawater (Fuhrman \& Ferguson 1986).

The lowest apparent half saturation constants for net DMSPd loss reported by Ledyard \& Dacey (1996) for whole Vineyard Sound, MA, USA, water (28 and $48 \mathrm{nM}$ ) are about a factor of 10 higher than our measured $K_{\mathrm{t}}+S_{\mathrm{n}}$ values for ${ }^{14} \mathrm{C}$-GBT in filtrate cultures, but are comparable to those we measured in whole seawater from offshore sites in the Gulf of Mexico (22 and $49 \mathrm{nM}$ ) (Kiene \& Hoffmann Williams unpubl.). Ledyard \& Dacey, however, also observed much higher apparent $K_{\mathrm{m}}$ values (100s of $\mathrm{nM}$ ) for net DMSP loss on some of their sampling dates and these were comparable to $K_{\mathrm{m}}$ values measured in a bacterium (105 to $280 \mathrm{nM}$ ) isolated from the Sargasso Sea (Ledyard \& Dacey 1994). The half saturation constants we measured in filtrate cultures (Table 1), and in whole water (Kiene \& Hoffmann Williams unpubl.) using radiolabeled substrates, appear to be somewhat lower as compared with those determined from net DMSPd loss rates (Kiene \& Service 1991, Ledyard \& Dacey 1994, 1996, Kiene 1996b). These differences could simply be due to differences in the microbial assemblages and the small number of data sets available for comparison, but could also reflect differences in the techniques employed. Using the radiolabeled substrates, we focused on the very low concentration range and we used very short incubations (<10 min). Measurements of DMSPd loss using gas chromatography typically have involved higher levels of added DMSP and incubation times of several hours. The lower affinity (high $K_{\mathrm{t}}$ ) DMSP uptake systems observed in other studies (Kiene \& Service 1991, Ledyard \& Dacey 1994, 1996, Kiene 1996b) might be important for bacteria which experience patches of high DMSPd concentration, such as those which might occur around a leaking phytoplankter.

The results of the cold chase experiment (Fig. 7) suggest that a significant portion of the recently acquired GBT is exchangeable with the extracellular environment. Our study did not distinguish between cell surface binding of the substrates and actual transport of the substrate through the cell membrane and into the cytoplasm. We simply captured labeled particulate material (cells) on filters. We speculate that, after capture by the cells, GBT may remain bound to the cell surface or in the periplasm associated with a binding protein, awaiting further transport or degradation. The Pro U system which transports GBT and proline in Escherichia coli has been found to consist of multiple components, including outer and inner membrane porins, as well as a specific periplasmic binding protein (Le Rudulier et al. 1996). Moreover, evidence for the involvement of a periplasmic binding protein in DMSP transport in Pseudomonas doudoroffii was recently found (Yoch et al. 1997). In addition to the cold chase results, several other lines of evidence suggest that GBT and DMSP are weakly held. In preliminary uptake experiments we observed that formalin caused major losses of ${ }^{14} \mathrm{C}$-GBT already taken into the particulate fraction (data not shown). Our findings in this regard are consistent with those of Wolfe (1996), who found that DMSP accumulated by seawater-grown bacteria was released upon heat or formalin treatments. In addition, we have found that relatively harsh filtration, such as occurs with polycarbonate membrane filters (10 cm Hg vacuum), caused significant $(\sim 50 \%)$ losses of ${ }^{14} \mathrm{C}-\mathrm{GBT}$ and ${ }^{35} \mathrm{~S}$-DMSP from particulates during the first few hours of incubation, when most of the isotope was identifiable as untransformed substrate in the cells (Kiene unpubl.). After longer incubations, when most of the GBT or DMSP had been transformed, the filter differences diminished. Obviously, further study of the GBT/DMSP uptake system in representative bacterial isolates from seawater will be needed in order to fully elucidate the mechanisms of GBT/DMSP transport.

\section{Ecological implications for the microbial community}

The GBT/DMSP transport system in seawater microorganisms may function as a mechanism for acquisition of osmoprotectants and energy substrates, as both DMSP and GBT are retained to some degree by natural bacterioplankton, in addition to being degraded (Kiene \& Hoffmann Williams unpubl., Walker \& Kiene unpubl.; see also Fig. 7). The requirements of marine bacterioplankton for osmoprotectants at the ambient salinities of seawater are presently unknown and this is something which needs investigation. GBT is well known for its ability to extend the range of salinities at which growth and metabolism of bacteria can take place (Le Rudulier \& Bouillard 1983, Smith et al. 1988, Riou \& Le Rudulier 1990), and DMSP has been found to have this ability as well (Mason \& Blunden 1989, Diaz et al. 1992). It is possible that sub-populations of bac- 
teria compete for GBT and DMSP for use as either osmoprotectants or energy substrates. The relative amount of retention or degradation of these compounds might also reflect the levels of stress on micro organisms, with possible stresses including osmotic condition, temperature or nutrient limitation. Regulation of GBT metabolism by salinity stress may explain why GBT degradation was considerably lower, and its retention in cells higher, in estuarine filtrates which had the salinity raised to seawater levels (35 ppt) (Kiene \& Hoffmann Williams unpubl.). The accumulation of DMSP in marine bacteria, as a response to increased osmolarity of the medium (Diaz et al. 1992, Wolfe 1996), or as a consequence of more rapid uptake than degradation (Ledyard \& Dacey 1994, Yoch et al. 1997), has been observed in a number of recent studies. Future studies should investigate the factors controlling the retention of GBT and DMSP in marine bacteria because this phenomenon could slow degradation of these compounds, and could also affect growth and metabolism of microorganisms if the compounds are used as osmolytes.

\section{Biogeochemical implications}

The existence of a high affinity uptake system for GBT and DMSP in seawater microbes is probably responsible for maintaining low pseudo-steady-state dissolved concentrations of these substrates in seawater. The concentrations of dissolved GBT in seawater have not yet been determined because currently available methods are not sensitive enough to detect it at nM levels in seawater. Dissolved DMSP (DMSPd), on the other hand, has been measured at concentrations ranging from 1 to $100 \mathrm{nM}$ in surface waters, with most concentrations in non-phytoplankton bloom situations being less than $10 \mathrm{nM}$ (Turner et al. 1988, Kiene 1996b). It might be expected that dissolved GBT concentrations would fall within this same range, and recent kinetic studies using whole seawater support this supposition (Kiene \& Hoffmann Williams unpubl.). Because dissolved DMSP and, by inference, GBT are released during food web processes (Christaki et al. 1996), their efficient scavenging will result in short turnover times. This inference is supported by the findings of several recent studies. Turnover times for DMSPd on the order of hours in Gulf of Mexico waters, and hours to days in Sargasso Sea and Vineyard Sound waters have been determined using gas-chromatographybased measurements of DMSP losses (Kiene 1996b, Ledyard \& Dacey 1996). Turnover times for GBT in Gulf of Mexico waters, based on kinetic analyses, were less than $12 \mathrm{~h}$ (Kiene \& Hoffmann Williams unpubl.).

Our finding that GBT and DMSP uptake are similar (Fig. 6) argues that ${ }^{14} \mathrm{C}$-GBT could serve as a useful proxy for estimating DMSP uptake and turnover rates. ${ }^{14} \mathrm{C}$-GBT is easily, and inexpensively, made from commercially available ${ }^{14} \mathrm{C}$-choline (King 1987), and may be more readily obtained than radiolabeled DMSP. Our preliminary direct comparisons of ${ }^{14} \mathrm{C}-\mathrm{GBT}$ and ${ }^{35} \mathrm{~S}$ DMSP uptake kinetics (Fig. 6) suggest that quantitative rate data based on GBT uptake will be close to those for DMSP, within a reasonable margin of error. Rigorous proof of this contention will require further testing.

\section{Potential interactions between GBT and DMSP in seawater}

The nearly identical uptake patterns we observed for both GBT and DMSP (Fig. 6), and the evidence that they act as competitive inhibitors of their respective uptake, argue that the fates of these compounds will be intimately linked. Release of one compound might inhibit the uptake and degradation of the other, at least in the short term. Kiene \& Service (1993) found that additions of 0.5 to $5 \mu \mathrm{M}$ GBT caused DMS concentrations to increase in seawater, most likely because GBT caused dissolved DMSP to accumulate. Kiene \& Gerard (1995) subsequently confirmed that GBT was a potent inhibitor of DMSP degradation in seawater and that it caused DMSPd to accumulate. These same authors pointed out that the availability of GBT could also affect the relative magnitude of competing degradation pathways (cleavage vs demethylation) for DMSP. For example, if GBT is particularly abundant, the demethylation pathway might utilize the methyl groups of GBT and leave more DMSP available for cleavage to DMS. Such an interaction might help to explain the large variability in the yields of DMS observed during DMSP degradation in coastal and oceanic waters (Kiene 1996a, Ledyard \& Dacey 1996). It is also conceivable that, over longer time scales, high levels of one compound might stimulate metabolism of the other due to induction of uptake/degradation systems and selection of DMSP/GBT utilizing microbial populations. The latter may explain why, in a previous study, DMSP degradation resumed only $6 \mathrm{~h}$ after addition of a 1000-fold excess of GBT (Kiene \& Gerard 1995). Undoubtedly, future research on the use of GBT and DMSP by microbial communities will face no shortage of interesting and challenging questions.

Acknowledgements. We thank Laura Linn for assistance with some of the experiments. Special thanks are offered to Gordon Wolfe who made helpful suggestions during the research cruise in the Gulf of Maine and who provided a critical review of this manuscript. Funding was provided by Chemical and Biological Oceanography Programs of the National Science Foundation, under grants OCE-9218511 and OCE-95-30378. 


\section{LITERATURE CITED}

Abee T, Palmen R, Hellingwerf KJ, Konings WN (1990) Osmoregulation in Rhodobacter sphaeroides. J Bacteriol 172:149-154

Andreae MO (1990) Ocean-atmosphere interactions in the global biogeochemical sulfur cycle. Mar Chem 30:1-29

Ansede JH, Yoch DC (1997) Comparison of selenium and sulfur volatilization by dimethylsulfoniopropionate (DMSP) lyase in two marine bacteria and estuarine sediments. FEMS Microbiol Ecol 23:315-324

Anthoni U, Christophersen C. Hougaard L, Nielsen PH (1991) Quaternary ammonium compounds in the biosphere-an example of a versatile ad.aptive strategy. Comp Biochem Physiol 99B:1-18

Azam F, Hodson RE (1981) Multiphasic kinetics for D-glucose uptake by assemblages of natural marine bacteria. Mar Ecol Prog Ser 6:213-222

Boch J, Kempf B, Bremer E (1994) Osmoregulation in Bacillus subtilis: synthesis of the osmoprotectant glycine betaine from exogenously provided choline. J Bacteriol 176: $5364-5371$

Burgermeister S, Zimmermann RL, Georgii HW, Bingemer HG, Kirst GO, Janssen M, Ernst W (1990) On the biogenic origin of dimethylsulfide: relation between chlorophyll, ATP, organismic DMSP, phytoplankton species, and DMS distribution in Atlantic surface water and atmosphere. J Geophys Res 95:20607-20615

Button DK (1991) Biochemical basis for whole cell uptake kinetics: specific affinity, oligotrophic capacity, and the meaning of the Michaelis constant. Appl Environ Microbiol 57:2033-2038

Cairney J, Booth IR, Higgins CF (1985) Salmonella typhimurium proP gene encodes a transport system for the osmoprotectant betaine. J Bacteriol 164:1218-1.223

Cavalieri AJ, Huang $\mathrm{HC}$ (1981) Accumulation of proline and glycinebetaine in Spartina alterniflora Loisel. in response to $\mathrm{NaCl}$ and nitrogen in the marsh. Oecologia (Berlin) 49:224-228

Charlson RJ, Lovelock JE, Andreae MO, Warren SG (1987) Oceanic phytoplankton, atmospheric sulfur, cloud albedo and climate. Nature 326:655-661

Choquet CG, Ahonkhai I, Klein M, Kushner DJ (1991) Formation and role of glycine betaine in the moderate halophile Vibrio costicola. Arch Microbiol 155:153-158

Christaki U, Belviso S, Dolan JR, Corn M (1996) An assessment of the role of copepods and ciliates in the release to solution of particulate DMSP. Mar Ecol Prog Ser 141. $119-127$

Coffin RB (1989) Bacterial uptake of dissolved free and combined amino acids in estuarine waters. Limnol Oceanogr $34: 531-542$

Cooke TD, Bruland KW (1987) Aquatic chemistry of selenium: evidence of biomethylation. Environ Sci Technol 21: $1214-1.219$

Diaz MR, Visscher PT, Taylor BF (1992) Metabolism of dimethylsulfoniopropionate and glycine betaine by a marine bacterium. FEMS Microbiol Lett 96:61-66

Ferguson RL, Sunda WG (1984) Utilization of amino acids by planktonic marine bacteria: importance of clean technique and low substrate additions. Limnol Oceanogr 29:258-274

Fuhrman JA (1987) Close coupling between release and uptake of dissolved free amino acids in seawater studied by an isotope dilution approach. Mar Ecol Prog Ser 37: $45-52$

Fuhrman JA, Ferguson RL (1986) Nanomolar concentrations and rapid turnover of dissolved free amino acids in sea- water: agreement between chemical and microbiological measurements. Mar Ecol Prog Ser 33:237-242

Galinski EA (1995) Osmoadaptation in bacteria. In: Advances in microbial physiology, Vol 37. Academic Press, New York, p 273-328

Gouesbet G, Jebbar M, Talibart R, Bernard T, Blanco C (1994) Pipecolic acid is an osmoprotectant for Escherichia coli taken up by the general osmoporters ProU and ProP. Microbiology 140:2415-2422

Grone T, Kirst GO (1992) The effect of nitrogen deficiency, methionine and inhibitors of methionine metabolism on the DMSP contents of Tetraselmis subcordiformis (Stein) Mar Biol 112:497-503

Hanaoka K, Matsumoto T, Tagawa S, Kaise T (1987) Microbial degradation of arsenobetaine, the major water soluble organoarsenic compound occurring in marine animals. Chemosphere 16:2545-2550

Hoffmann L.P (1996) Characterization of uptake and use of glycine betaine by marine phytoplankton and natural microbial assemblages. MSc thesis, Univ South Alabama

Iverson RL, Nearhoof FL, Andreae MO (1989) Production of dimethylsulfonium propionate and dimethylsulfide by phytoplankton in estuarine and coastal waters. Limnol Oceanogr 34:53-67

Kiene RP (1996a) Production of methane thiol from dimethylsulfoniopropionate in marine surface waters. Mar Chem $54: 69-83$

Kiene RP (1996b) Turnover of dissolved DMSP in estuarine and shelf waters from the Northern Gulf of Mexico. In: Kiene R, Visscher P, Keller M, Kirst G (eds) Environmental and biological chemistry of DMSP and related sulfonium compounds. Plenum Press, New York, p 337-349

Kiene RP (1998) Choline uptake by microorganisms in seawater and its conversion to glycine betaine. Appl Environ Microbiol 64: 1045-1051

Kiene RP, Gerard G (1995) Evaluation of glycine betaine as an inhibitor of dissolved dimethylsulfoniopropionate degradation in marine waters. Mar Ecol Prog Ser 128:121-131

Kiene RP, Service SK (1991) Decomposition of dissolved DMSP and DMS in estuarine waters: dependence on temperature and substrate concentration. Mar Ecol Prog Ser $76: 1-11$

Kiene RP, Service SK (1993) The influence of glycine betaine on dimethyl sulfide and dimethylsulfoniopropionate concentrations in seawater. In: Oremland RS (ed) The biogeochemistry of global change: radiatively important trace gases. Chapman and Hall, New York, p 654-671

King GM (1987) An enzymatic synthesis of specifically radiolabeled derivatives of the common osmolyte, glycine betaine. J Exp Mar Biol Ecol 107:145-154

King GM (1988) Distribution and metabolism of quaternary amines in marine sediments. In: Blackburn TH, Sorensen $J$ (eds) Nitrogen cycling in coastal marine environments. John Wiley, New York, p 143-173

Landfald B. Strom AR (1986) Choline-glycine betaine pathway confers a high level of osmotic tolerance in Escherichia coli. J Bacteriol 165:849-855

Le Rudulier D, Bouillard L (1983) Glycine betaine, an osmotic effector in Klebsiella pneumoniae and other members of the Enterobacteriaceae. Appl Environ Microbiol 46 $152-159$

Le Rudulier D, Pocard JA, Boncompagni E, Poggi MC. (1996) Osmoregulation in bacteria and transport of onium compounds. In: Kiene RP, Visscher PT, Keller MD, Kirst GO (eds) Biological and environmental chemistry of DMSP and related sulfonium compounds. Plenum Press, New York, p 253-263 
Ledyard KM, Dacey JWH (1994) Dimethylsulfide production from dimethylsulfoniopropionate by a marine bacterium. Mar Ecol Prog Ser 110:95-103

Ledyard KM, Dacey JWH (1996) Microbial cycling of DMSP and DMS in coastal and oligotrophic seawater. Limnol Oceanogr 41:33-40

Lee SH, Kang YC, Fuhrman JA (1995) Imperfect retention of natural bacterioplankton cells by glass fiber filters. Mar Ecol Prog Ser 119:285-290

Li WKW (1983) Consideration of errors in estimating kinetic parameters based on Michaelis-Menten formalism in microbial ecology. Limnol Oceanogr 28:185-190

Mason TG, Blunden G (1989) Quaternary ammonium and tertiary sulfonium compounds of algal origin as alleviators of osmotic stress. Bot Mar 32:313-316

Mopper K, Kieber DJ (1991) Distribution and biological turnover of dissolved organic compounds in the water column of the Black Sea. Deep Sea Res 38:\$1021-S1047

Perroud B, LeRudulier D (1985) Glycine betaine transport in Eschericia coli: osmotic modulation. J Bacteriol 161:393-401

Proctor LM, Lai R, Gunsalus RP (1997) The methanogenic archaeon Methanosarcina thermophila TM-1 possesses a high-affinity glycine betaine transporter involved in osmotic adaptation. Appl Environ Microbiol 63:2252-2257

Rhodes D, Hanson AD (1993) Quaternary ammonium and tertiary sulfonium compounds in higher plants. Annu Rev Plant Physiol Plant Mol Biol 44:357-384

Rich JH, Ducklow HW, Kirchman DL (1996) Concentrations and uptake of neutral monosaccharides along $140^{\circ} \mathrm{W}$ in the equatorial Pacific: contribution of glucose to hetero-

Editorial responsibility: Jed Fuhrman,

Los Angeles, California, USA trophic bacterial activity and DOM flux. Limnol Oceanogr 41:595-604

Riou N, Le Rudulier D (1990) Osmoregulation in Azospirillum brasilense: glycine betaine transport enhances growth and nitrogen fixation under salt stress. J Cien Microbiol 136:1455-1461

Roulier MA, Palenik B, Morel FMM (1990) A method for the measurement of choline and hydrogen peroxide in seawater. Mar Chem 30:409-421

Smith LT, Pocard J, Bernard T, Le Rudulier D (1988) Osmotic control of glycine betaine biosynthesis and degradation in Rhizobium meliloti. J Bacteriol 170:3142-3149

Turner SM, Malin G, Liss PS (1988) The seasonal variation of dimethyl sulfide and dimethylsulfoniopropionate concentrations in nearshore waters. Limnol Oceanogr 33:364-375

Wolfe GV (1996) Accumulation of dissolved DMSP by marine bacteria and its degradation via bactivory. In: Kiene RP Visscher PT, Keller MD, Kirst GO (eds) Biological and environmental chemistry of DMSP and related sulfonium compounds. Plenum Press, New York, p 277-291

Wright RT, Hobbie JE (1966) Use of glucose and acetate by bacteria and algae in aquatic ecosystems. Ecology 47 $447-464$

Yancey $\mathrm{PH}$, Clark ME, Hand SC, Bowlus RD, Somero GN (1982) Living with water stress: evolution of osmolyte systems. Science 217:1214-1222

Yoch DC, Ansede JH, Rabinowitz KS (1997) Evidence for intracellular and extracellular dimethylsulfoniopropionate (DMSP) lyases and DMSP uptake sites in two species of marine bacteria. Appl Environ Microbiol 63:3182-3188

Submitted: September 19, 1997; Accepted: January 5, 1998 Proofs received from author(s): April 22, 1998 